U.S. DEPARTMENT OF THE INTERIOR

U.S. GEOLOGICAL SURVEY

\title{
AEROMAGNETIC SURVEYS ACROSS CRATER FLAT AND PARTS OF Y UCCA MOUNTAIN, : NEVADA
}

$B y$

R.F. Sikora', D.L. Cam pbell'2, and R.P. Kucks ${ }^{2}$

1995
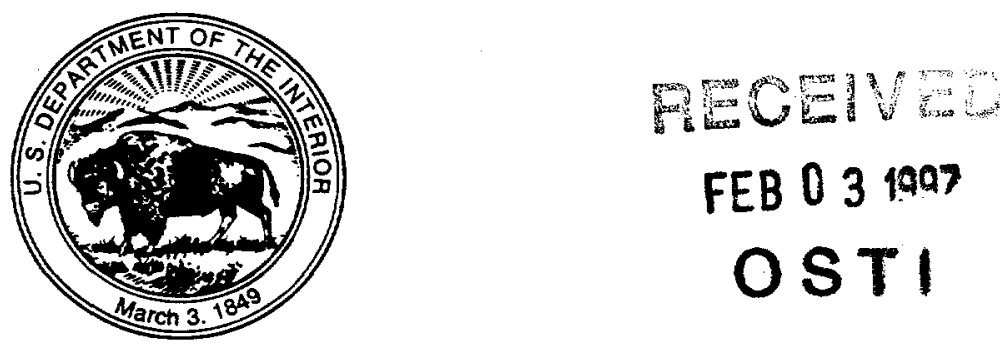

Open-File Report 95-812-A

95-812-A Report documentation

95-812-B Airborne magnetic data on diskette

This report is preliminary and has not been reviewed for conformity with U.S. Geological Survey editorial standards or with the North American Stratigraphic Code. Any use of trade, firm, or product names is for descriptive purposes only and does not imply endorsement by the U.S. Government.

Prepared in cooperation with the NEVADA OPERATIONS OFFICE

U.S. DEPARTMENT OF ENERGY

(Interagency Agreement DE-AI08-78ET44802)

Menlo Park, California

1995

1Menlo Park, CA

${ }^{2}$ Denver, CO 


\section{DISCLAIMER}

This report was prepared as an account of work sponsored by an agency of the United States Government. Neither the United States Government nor any agency thereof, nor any of their employees, make any warranty, express or implied, or assumes any legal liability or responsibility for the accuracy, completeness, or usefulness of any information, apparatus, product, or process disclosed, or represents that its use would not infringe privately owned rights. Reference herein to any specific commercial product, process, or service by trade name, trademark, manufacturer, or otherwise does not necessarily constitute or imply its endorsement, recommendation, or favoring by the United States Government or any agency thereof. The views and opinions of authors expressed herein do not necessarily state or reflect those of the United States Government or any agency thereof. 


\section{DISCLAIMER}

Portions of this document may be illegible in electronic image products. Images are produced from the best available original document. 
U.S. DEPARTMENT OF THE INTERIOR

U.S. GEOLOGICAL SURVEY

\section{A EROMA GNETIC SURVEY A CROSS CRA TER FLAT AND PARTS OF Y UCCA MOUNTAIN, NEVADA}

By

R.F. Sikora1, D.L. Campbel12, and R.P. Kucks ${ }^{2}$

1995

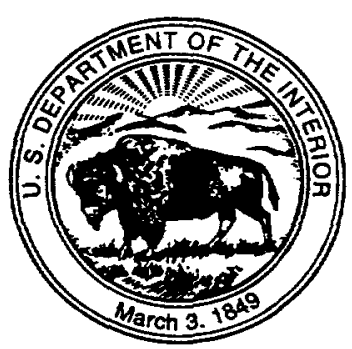

Open-File Report 95-812-A

95-812-A Report documentation

95-812-B Airborne magnetic data on diskette

This report is preliminary and has not been reviewed for conformity with U.S. Geological Survey editorial standards or with the North American Stratigraphic Code. Any use of trade, firm, or product names is for descriptive purposes only and does not imply endorsement by the U.S. Government.

Prepared in cooperation with the NEVADA OPERATIONS OFFICE U.S. DEPARTMENT OF ENERGY

(Interagency Agreement DE-AI08-78ET44802)

Menlo Park, California 1995

${ }^{1}$ Menlo Park, CA

${ }^{2}$ Denver, CO 
Copies of this Open-File Report may be purchased from:

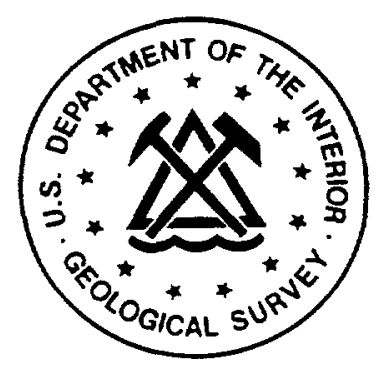

USGS Information Services

Box 25286, Bldg. 810

Denver Federal Center

Denver, CO 80225-0046

PREPAYMENT IS REQUIRED

FOR ADDITIONAL ORDERING INFORMATION

CALL: (303) 202-4210

$$
\begin{gathered}
\text { fax: (303) 202-4695 } \\
\text { 1-800-HELP-MAP } \\
\text { 1-800-USA-MAPS }
\end{gathered}
$$

Price information is available in the monthly listing:

New Publications of the U.S. Geological Survey

World Wide Web internet address:

http://pubs.usgs.gov/publications/index.html

USGS Home Page

http://www.usgs.gov 


\section{CONTENTS}

Abstract

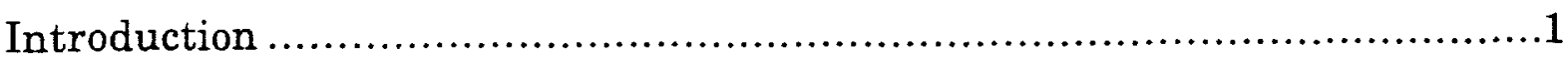

Acknowledgments...........................................................

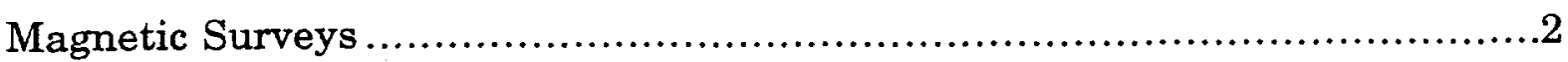

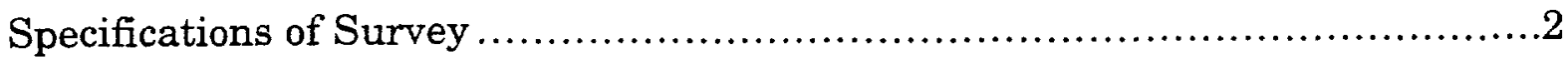

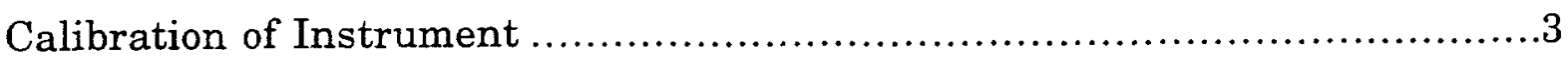

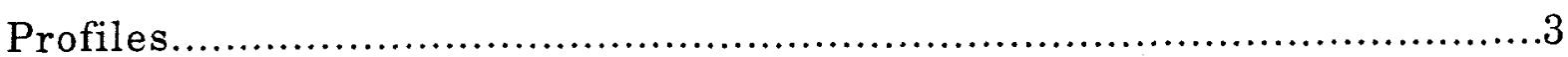

Major Anomalies ...........................................................

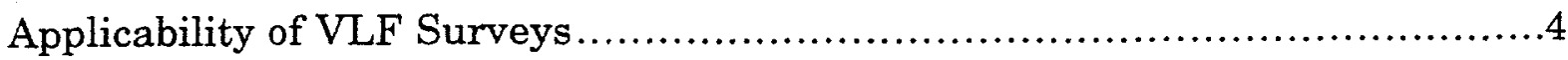

References...................................................................6

\section{ILUSTRATIONS}

FIGURE 1. Aeromagnetic map along profiles across Crater Flat and Yucca Mountain, Nevada...................................................7

FIGURE 2. Timber Mountain area aeromagnetic survey $\ldots \ldots \ldots \ldots \ldots \ldots \ldots \ldots \ldots . \ldots$

FIGURE 3-1 thru 3-15.

Aeromagnetic profiles across Crater Flat and parts of Yucca Mountain, Nevada. 


\title{
Aeromagnetic Surveys Across \\ Crater Flat and Parts of \\ Yucca Mountain, Nevada
}

by

R.F. Sikora, D.L. Campbell, and R.P. Kucks

\begin{abstract}
As part of a study to characterize a potential nuclear waste repository at Yucca Mountain, aeromagnetic surveys were conducted in April 1993 along the trace of a planned seismic profile across Crater Flat and parts of Yucca Mountain. This report includes a presentation and preliminary interpretation of the data. The profiles are at scales of 1:100,000. Also included are a gridded color contour map of the newly acquired data and a discussion of the likely applicability of very-lowfrequency (VLF) electromagnetic surveys to Yucca Mountain investigations.
\end{abstract}

\section{Introduction}

Aeromagnetic surveys were flown by the U.S. Geological Survey (USGS) over Crater Flat and part of Yucca Mountain, Nevada, to help in the interpretation of the subsurface geologic structure at a potential location of a nuclear waste repository. The USGS airplane was in the Yucca Mountain vicinity to fly an extensive aeromagnetic and VLF survey of the Beatty area just to the west. The lines reported here followed the trace of proposed seismic profiles (Brocher and others, 1996) and were added to the primary job at Beatty as a target of opportunity. This report briefly discusses features seen on the aeromagnetic profiles and their possible sources. These data will eventually be used along with results from other studies, including the proposed seismic surveys, to help make the final interpretation. 


\section{Acknowledgments}

Thanks to D.A. Ponce for his help at different stages of this report. He initiated the study, assisted with programs, and provided a helpful technical review. Thanks also to R.J. Bisdorf for his constructive revie and to T.G. Hildenbrand for his help in data format conversions. Quality assurance review was performed by Martha Mustard, a preliminary policy review was performed by Bob Lewis, and a geologic names review by Clay Hunter, Yucca Mountain Project.

\section{Magnetic Surveys}

Magnetic surveys are used to help locate and identify the sources of anomalies in the Earth's magnetic field. Magnetic anomalies may be related to near-surface geology or to geologic structural features within the Earth's crust. Magnetic data may reveal the existence of faults, the distribution of stratigraphic units, the presence of intrusive bodies, the thickness and shape of sedimentary basins, and the depth to the bottom of magnetic sources. Magnetic anomalies will tend to form along boundaries where there is a vertical offset of beds (Bath and others, 1982).

\section{Specifications of Survey}

Under the direction of Roy Kipfinger, party chief, the pilot Chuck Thompson, and the co-pilot Dick Sneddon flew 106.2 miles $(171 \mathrm{~km})$ of aeromagnetic profile data on April 26, 1993. The profiles were flown at $300 \mathrm{ft}(91 \mathrm{~m})$ above ground level (radar controlled) and are at $0.25 \mathrm{mi}(0.40 \mathrm{~km})$ spacing. The average speed of the aircraft was 90 nautical miles per hour. The flight lines were flown in groups of three, with the center line following the proposed seismic profiles, and with an additional line out to each side (fig. 1). The aeromagnetic data were measured using Geometrics model G813 proton precession airborne magnetometers mounted on the wing-tip or tail stinger and recorded on a GR33 chart recorder (recording pitch, roll, radar altimetry, heading, VLF and magnetic readings), digital tape, and video backup for flightline recovery. The sensitivity was 0.5 nanoteslas (nT), and the cycle time was 0.5 seconds. Global Positioning System (GPS) was used as the primary navigation system. 


\section{Calibration of Instrument}

A calibration check of the airborne magnetometer was conducted using a certified Geometrics G856 base station magnetometer, which is calibrated following guideline specifications. The purpose of calibration is to assure the accuracy, validity, and applicability of the methods used to collect, process and interpret magnetic data.

\section{Profiles}

The profile data are displayed in figures 3-1 through 3-15 at a scale of 1:100,000. All profiles are displayed with west to the left.

\section{Major Anomalies}

The gridded and contoured aeromagnetic survey data (fig.1) show a number of magnetic features that can also be seen on a detailed aeromagnetic map (fig. 2) of the Timber Mountain area (U.S. Geological Survey, 1979). A broad magnetic low in the western third of profiles 1,2 , and 3 may be due to reversely magnetized tuffs (Kane and Bracken, 1983). These tuffs are Miocene in age and consist of quartzand hornblende-bearing rhyolitic ash-flow tuffs (Carr and others, 1986). However, Langenheim and Ponce (1995) suggest that this anomaly may be related to a reversely magnetized basalt flow that was penetrated in drill-hole USW VH-2 (Carr and Parrish, 1985).

A broad magnetic high occurs just south of Black Cone, on profiles 1,2 , and 3 and 4,5 , and 6 . The source of this high is unknown but may be due to buried normally magnetized volcanic rocks if they thicken towards the center of the anomaly (Kane and Bracken, 1983). A hole drilled over this anomaly revealed about $300 \mathrm{~m}(984 \mathrm{ft}$ ) of Topopah Spring Tuff of the Paintbrush Group (Sawer and others, 1994) and over $140 \mathrm{~m}$ (459 ft) of densely welded Bullfrog Member of the Crater Flat Tuff (Carr, 1985). Kane and Bracken (1983) suggest that both of these units have magnetic properties that could cause the anomaly. Physical property measurements by Rosenbaum and Snyder (1984) show that both these units are normally magnetized. 
A deep north trending low in the middle of lines 4, 5, and 6 is ascribed by Kane and Bracken (1983) to a possible offset in underlying horizontal tuffs. Magnetic highs over Yucca Mountain, at the northeast end of lines 10,11, and 12 and the northwestern two-thirds of lines 13,14 , and 15, generally correlate with exposures of the Topopah Spring Tuff of the Paintbrush Group (Sawyer and others, 1994). Kane and Bracken (1983) speculate that linear magnetic features in this area may reflect offsets in flat-lying volcanic units. Such offsets may only represent lithologic causes, such as variations in thickness or magnetic properties of the volcanic units, or they could be due to tectonic elements, such as faults (Bath and others, 1982). Joint interpretation of these data together with seismic and other data still to come should help resolve the nature of these possible offsets.

\section{Applicability of VLF Surveys}

The USGS airplane that flew the Crater Flat aeromagnetic lines was outfitted with a Very Low Frequency (VLF) receiver. This VLF receiver was developed by the Branch of Geophysics for making maps of the electrical resistivity of surficial units (Flanigan and others, 1986).

VLF electromagnetic waves are broadcast by U.S. Navy navigation stations located along the coasts. Commonly used stations in the conterminous United States are Cutler, ME $(24.4 \mathrm{kHz})$ and Seattle, WA $(24.0 \mathrm{kHz})$. As the VLF waves propagate, they are affected by electrical resistivities of the near-surface geologic units. These effects are detected by the airborne receiver and are then inverted to infer a VLF resistivity value, a weighted average of true rock resistivities between the surface and a depth of about $100 \mathrm{ft}$.

One objective of the Crater Flat airborne work was to determine whether airborne VLF resistivity data might be useful for Yucca Mountain investigations. Unfortunately, the VLF equipment was not functional on the day the Crater Flat and Yucca mountain lines were flown, so we have no VLF data along those particular lines. As mentioned above, however, the USGS airplane was in the Yucca Mountain vicinity mainly to fly an aeromagnetic and VLF survey of the Beatty area just to the northwest -- the Crater Flat lines had been added to this primary job as a target of opportunity. It happens that good VLF data were acquired over this nearby block of ground. From the Beatty survey results, we 
can confidently report that airborne VLF data, if acquired at Yucca Mountain, would be useful for certain Yucca Mountain site characterization purposes.

-Measured VLF resistivity values for the Beatty survey range from $45 \mathrm{ohm}-\mathrm{m}$ to $1,000 \mathrm{ohm}-\mathrm{m}$. Generally, the high resistivities ( $>500 \mathrm{ohm}-\mathrm{m}$ ) reflect outcrops of crystalline rocks; low resistivities $(<500 \mathrm{ohm}-\mathrm{m})$ reflect soils and surficial materials; and the lowest resistivities ( $<100 \mathrm{ohm}-\mathrm{m}$ ) reflect wet ground with seeps and springs. It doesn't seem possible to distinguish particular geological formations using only resistivity values. Locally, high-resistivity zones extend from crystalline rock outcrops out into the valleys; presumably, the VLF is mainly seeing crystalline rock there, under a thin cover of valley-fill material. If VLF data were available from Crater Flat, it is possible a similar effect might be observed, where the graben edge is likely covered by sediments.

Springs may not necessarily show up as lows on the VLF resistivity map. A possibility, not yet verified, is that springs along vertical faults produce resistivity lows while seeps along outcropping tops of flat confining units do not. This makes sense from a theoretical standpoint, at least, since a saturated fault zone might extend to depth, so that the weighted-average VLF resistivity from it would be lower than that due to a thin saturated zone with resistive rocks above and below it. Recall that early electrical work done on the surface at Yucca Mountain showed certain fault zones to be resistivity lows (Klein, 1990).

Because of the geometry of VLF fields, different stations couple more or less well to linear conductors such as possible faults. In the Beatty study area, with eastwest flight lines, features trending north-south showed up better on the Cutler data than the Seattle data. Ideally, two such VLF stations at azimuths 90 degrees apart should be recorded simultaneously so as to detect features trending in all directions, although features trending parallel to flight lines will always be less well resolved than these perpendicular to flight lines. 


\section{References}

Bath, G.D., Dixon, G.L., and Rosenbaum, J.G., 1982, Relation of aeromagnetic anomalies to faulted volcanic terrains at the Nevada Test Site (abs.): Geological Society of America, Rocky Mountain Section, 35th Annual Meeting, Abstracts with Program, v. 14, no. 6, p. 302.

Brocher, T.M., Hart, P.E., Hunter, W. Clay, and Langenheim, V.E., 1995, Hybrid-source seismic reflection profiling across Yucca Mountain, Nevada: Regional lines 2 and 3: U.S. Geological Survey Open-File Report.

Carr, W.J., 1982, Volcano-tectonic history of Crater Flat, southwestern Nevada, as suggested by new evidence from drill hole USW.VH-1 and vicinity: U.S. Geological Survey Open-File Report 82-457, $23 \mathrm{p}$.

Carr, W.J. and Parish, L.D., 1985, Geology of Drill Hole USW VH.2 and structure of Crater Flat, southwestern Nevada: U.S. Geological Survey Open-File Report 84-474, 41 p.

Carr, W.J., Beyers, F.M., Jr., and Orkild, P.P., 1986, Stratigraphic and tectonic relations of Crater Flat Tuff and some older volcanic units, Nye County, Nevada: U.S. Geological Survey Professional Paper 1323, 28 p.

Flanigan, V.J., Long, C.L., Rohret, D.H., and Mohr, P.J., 1986, Apparent resistivity map of the rift systems of Kilauea and Mauna Loa volcanoes, Island of Hawaii, Hawaii: U.S. Geological Survey Map Miscellaneous Field Investigations MF-1845B.

Kane, M.F. and Bracken, R.E., 1983, Aeromagnetic map of the Yucca Mountain and surrounding regions, southwest, Nevada: U.S. Geological Survey Open-File Report 83-616, 19 p.

Klein, D.P., 1990, Geoelectric Surveys, Chapter 2.3 in Oliver, H.W., Hardin, E.L., and Nelson, P.H., eds., Status of data, major results, and plans for geophysical activities, Yucca Mountain Project, U.S. Geological Survey for the Department of Energy: Department of Energy Report, Yucca Mountain Project, YMP/90-38, p. 33-46.

Langenheim, V.E., and Ponce, D.A., 1995, Ground magnetic studies along a regional seismicreflection profile across Bare Mountain, Crater Flat, and Yucca Mountain, Nevada: U.S. Geological Survey Open-File Report 95-834, 36 p.

Rosenbaum, J.G., and Snyder, R.B., 1985, Preliminary interpretation of paleomagnetic and magnetic property data from drill holes USW G-1, G-2, G-3, and VH-1 and surface localities in the vicinity of Yucca Mountain, Nye County, Nevada: U.S. Geological Survey Open-File Report 85-49, 73 p.

Sawer, David A., Fleck, R.J., Lanphere, M.A., Warren, R.G., Broxton, D.E., Hudson, M. R., 1994, Episodic caldera volcanism in the Miocene southwestern Nevada volcanic field: Revised stratigraphic framework, ${ }^{40} \mathrm{AR} /{ }^{39} \mathrm{AR}$ geochronology, and implications for magnetism and extension: Geological Society of America Bulletin, v. 106, p. 1304-1318.

U.S. Geological Survey, 1979, Aeromagnetic map of the Timber Mountain area, Nevada: U.S. Geological Survey Open-File Report 79-587, 3 sheets, scale 1:62,500. 


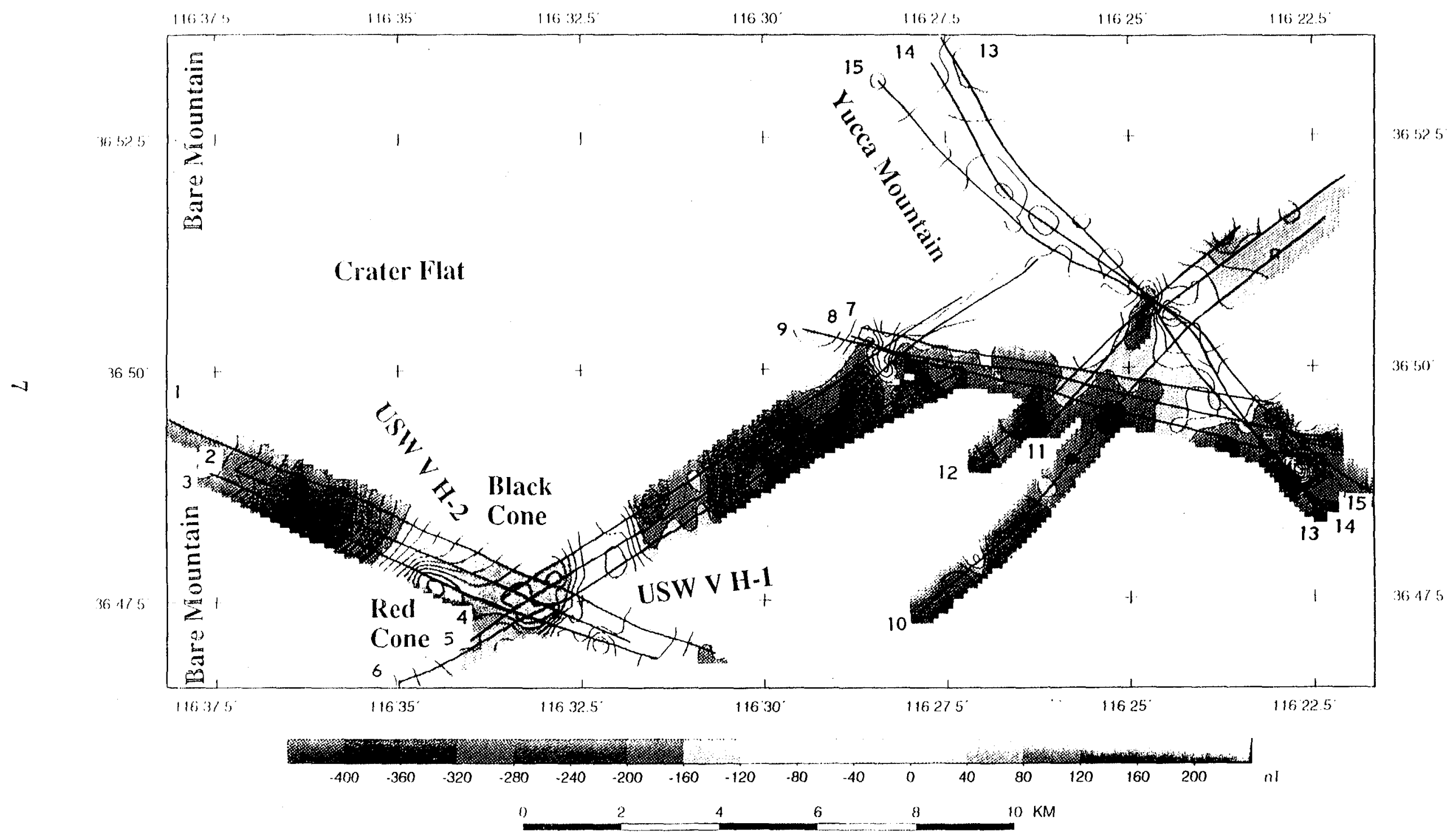

FHiUkE: 1. Aeromagnetic map along profiles across Crater Flat and parts of Yucca Mountain, Nevada $(90 \mathrm{~m}$ (300 $\mathrm{ft}$ ) above the ground and $0.40 \mathrm{~km}(0.25 \mathrm{mi})$ spacing). 


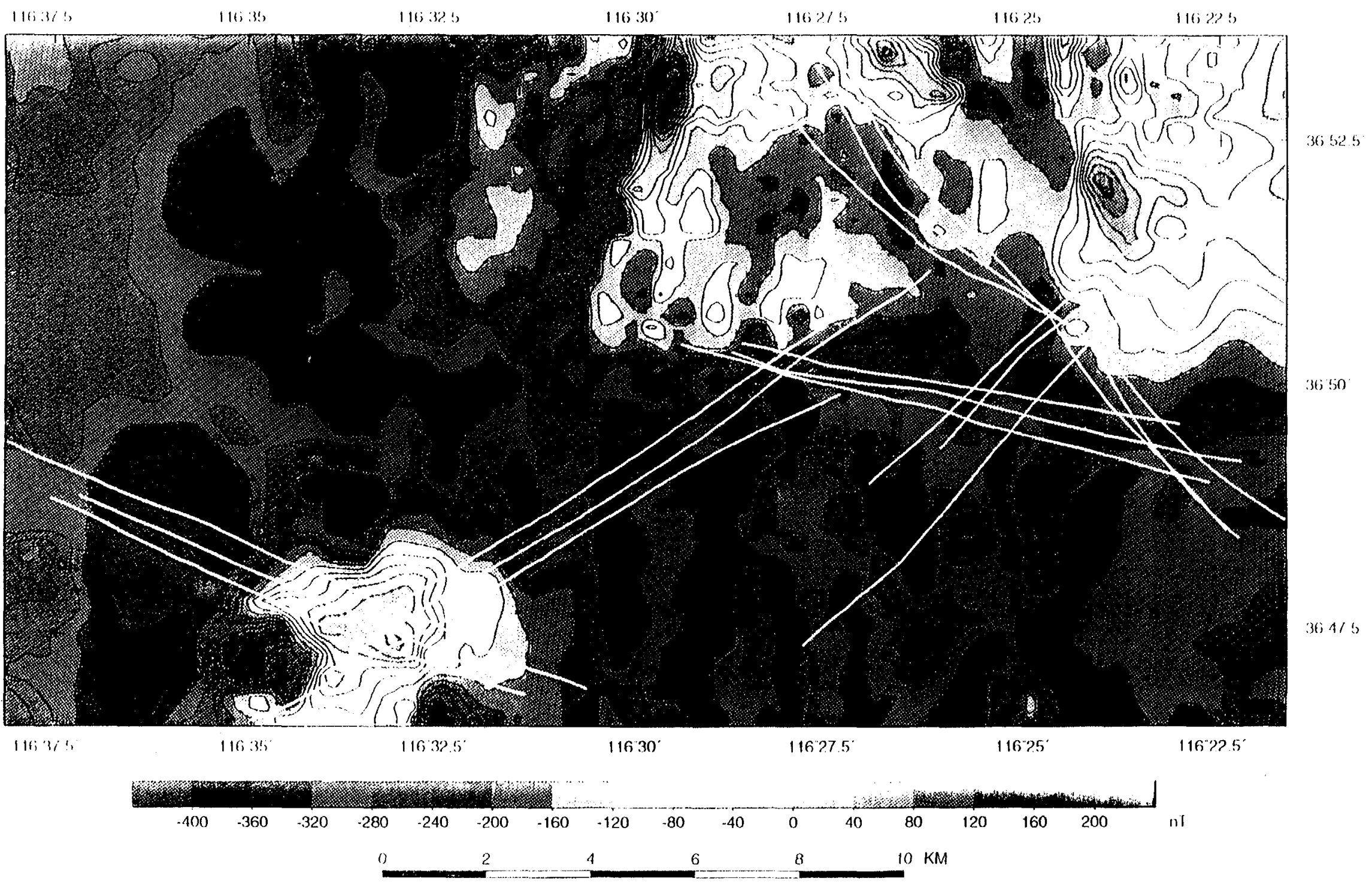

FIGURE 2. Aeromagnetic map of the Timber Mountain area $(0.12 \mathrm{~km}(394 \mathrm{ft})$ drape flown above ground and at $0.40 \mathrm{~km}(1,312 \mathrm{ft})$ spacing in $\mathrm{E}-\mathrm{W}$ direction and IGRF gradient removed), U.S. Geological Survey (1979). 


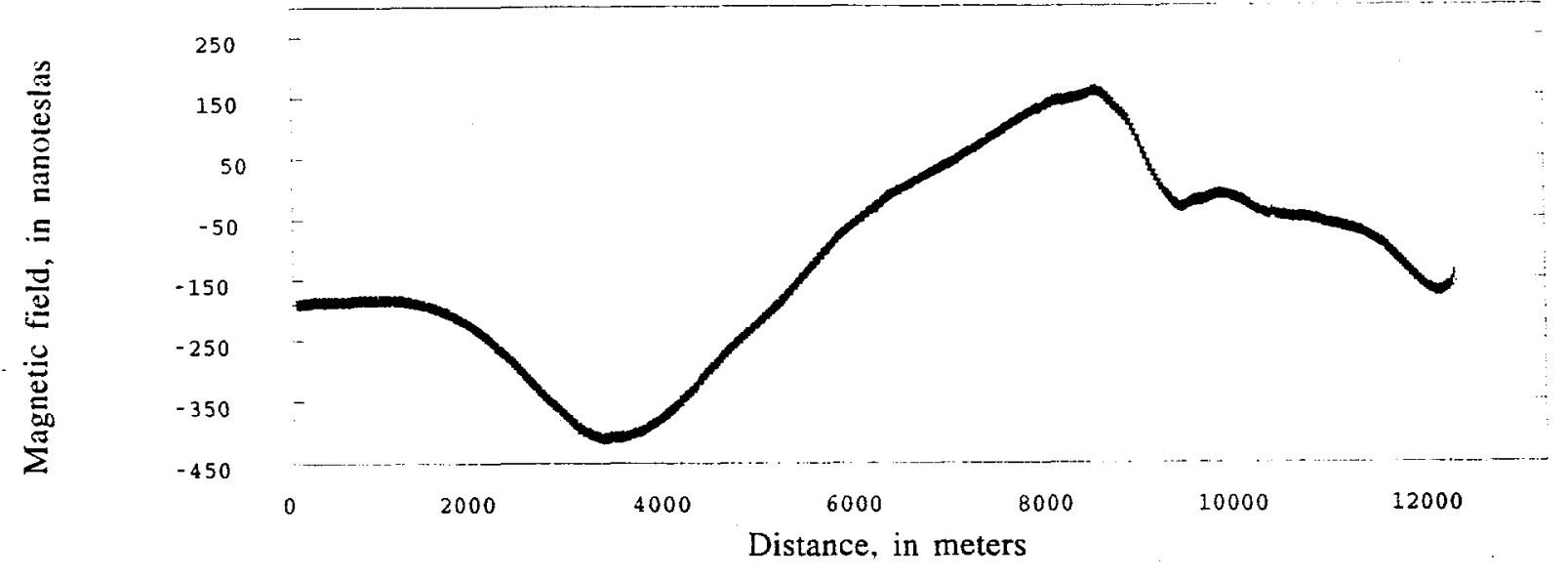

Figure 3-1. Aeromagnetic profile across Crater Flat and parts of Yucca Mountain, Nevada:

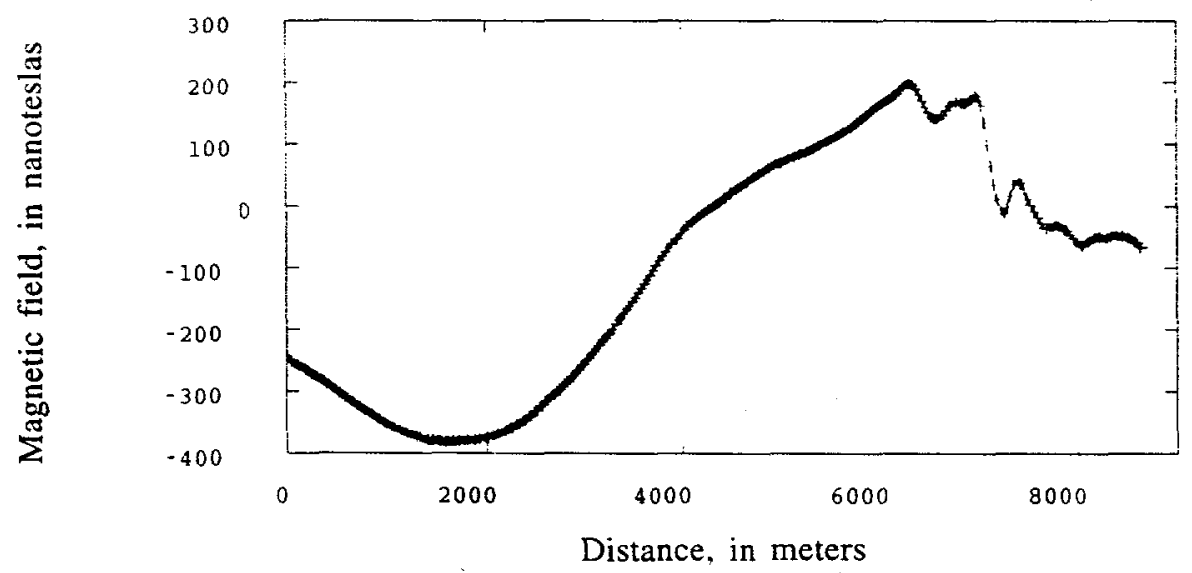

Figure 3-2. Aeromagnetic profile across Crater Flat and parts of Yucca Mountain, Nevada.

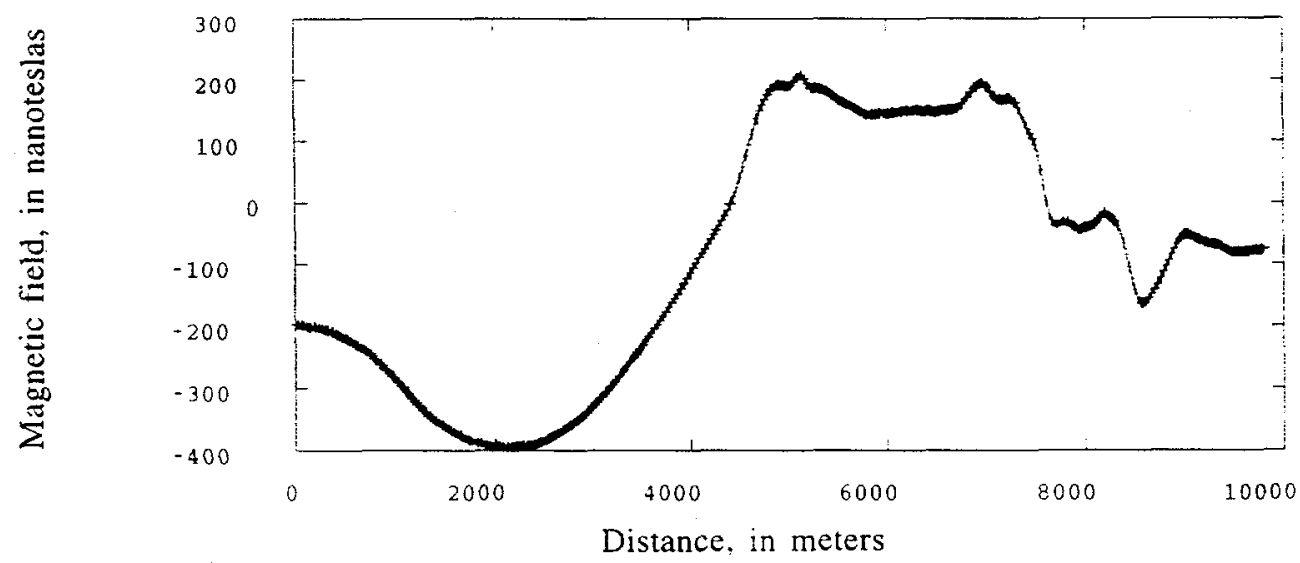

Figure 3-3. Aeromagnetic profile across Crater Flat and parts of Yucca Mountain, Nevada. 


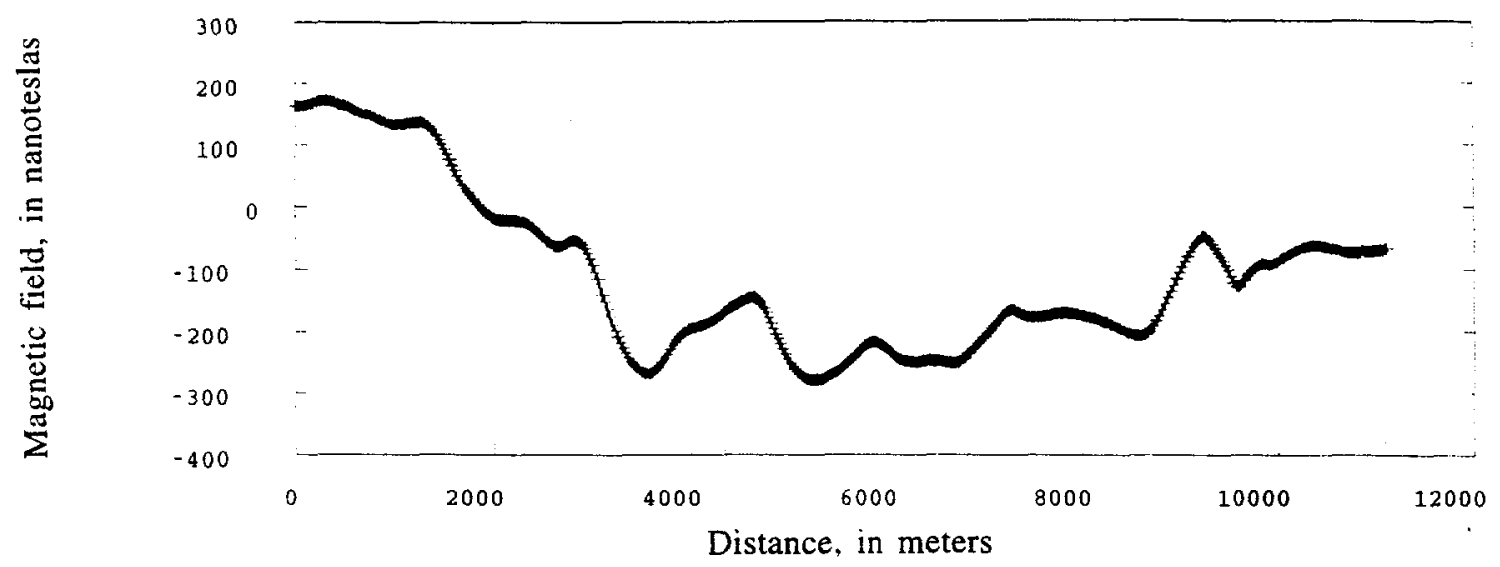

Figure 3-4. Aeromagnetic profile across Crater Flat and parts of Yucca Mountain, Nevada.

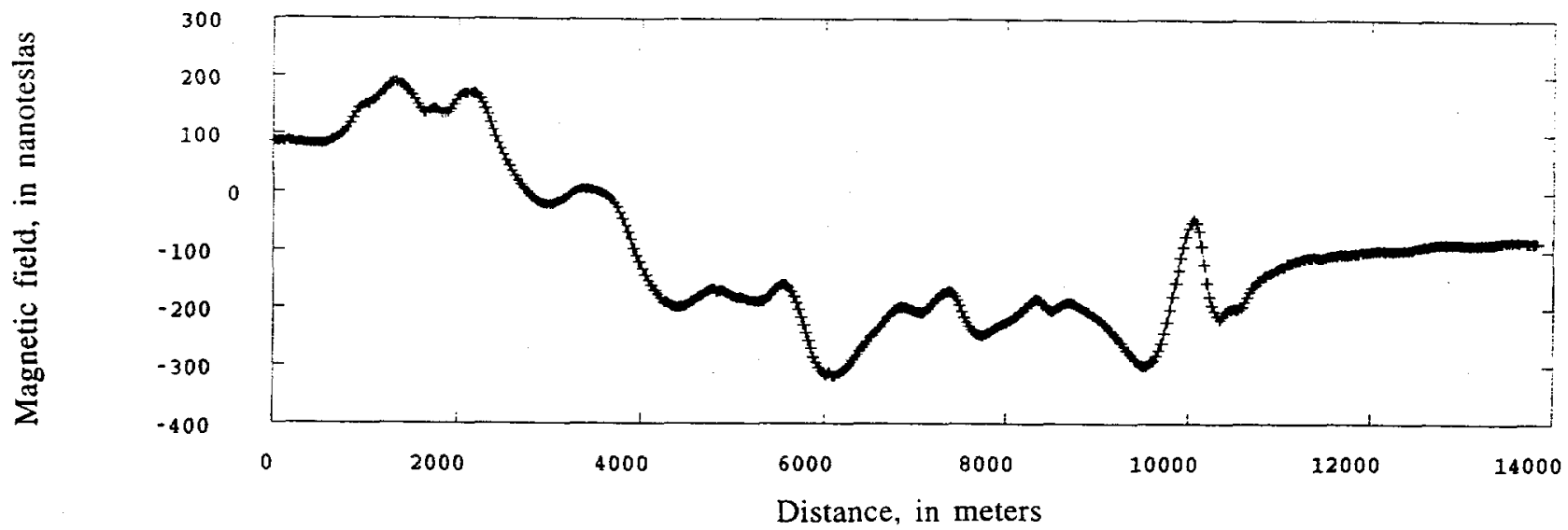

Figure 3-5. Aeromagnetic profile across Crater Flat and parts of Yucca Mountain, Nevada.

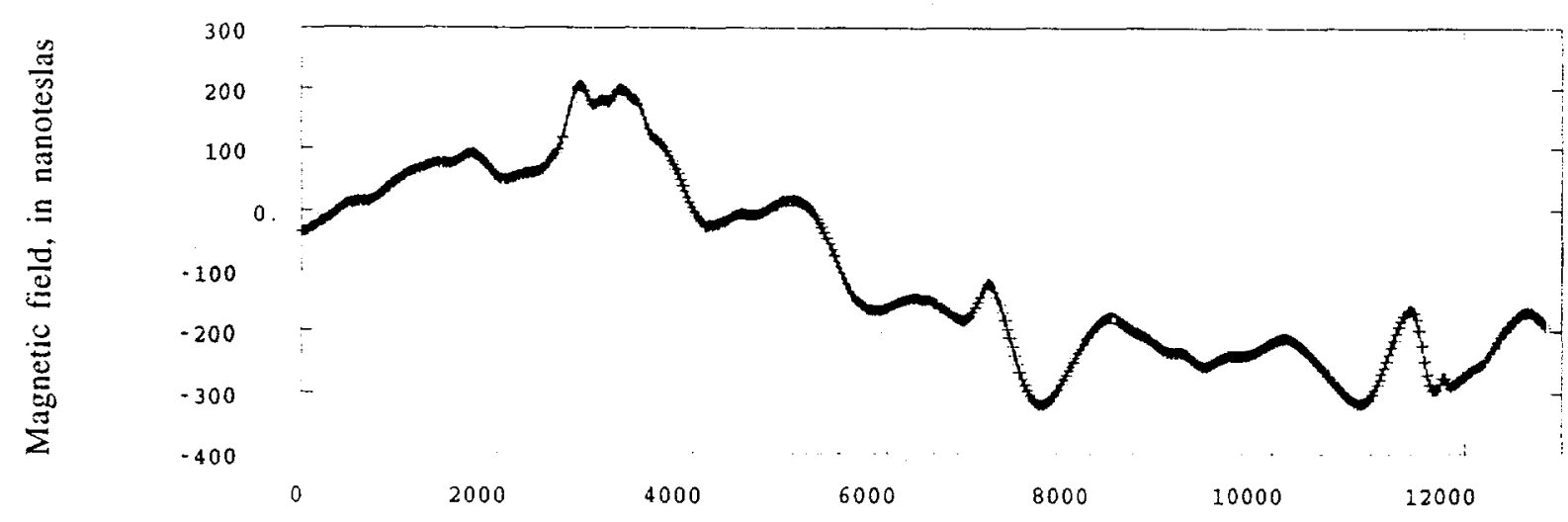

Distance, in meters

Figure 3-6. Aeromagnetic profile across Crater Flat and parts of Yucca Mountain, Nevada. 


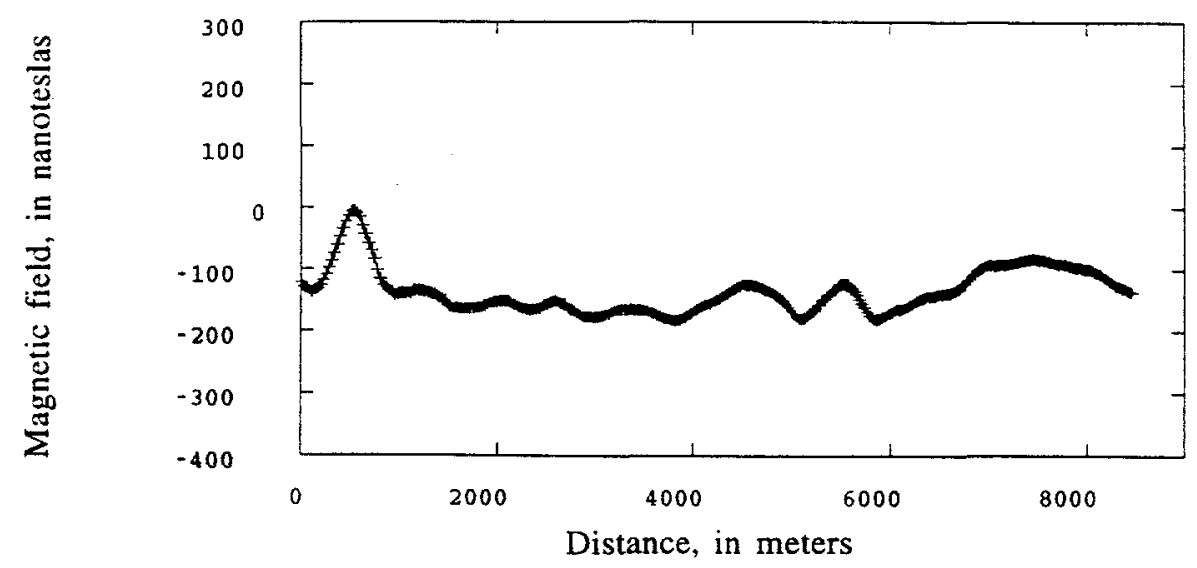

Figure 3-7. Aeromagnetic profile across Crater Flat and parts of Yucca Mountain, Nevada.

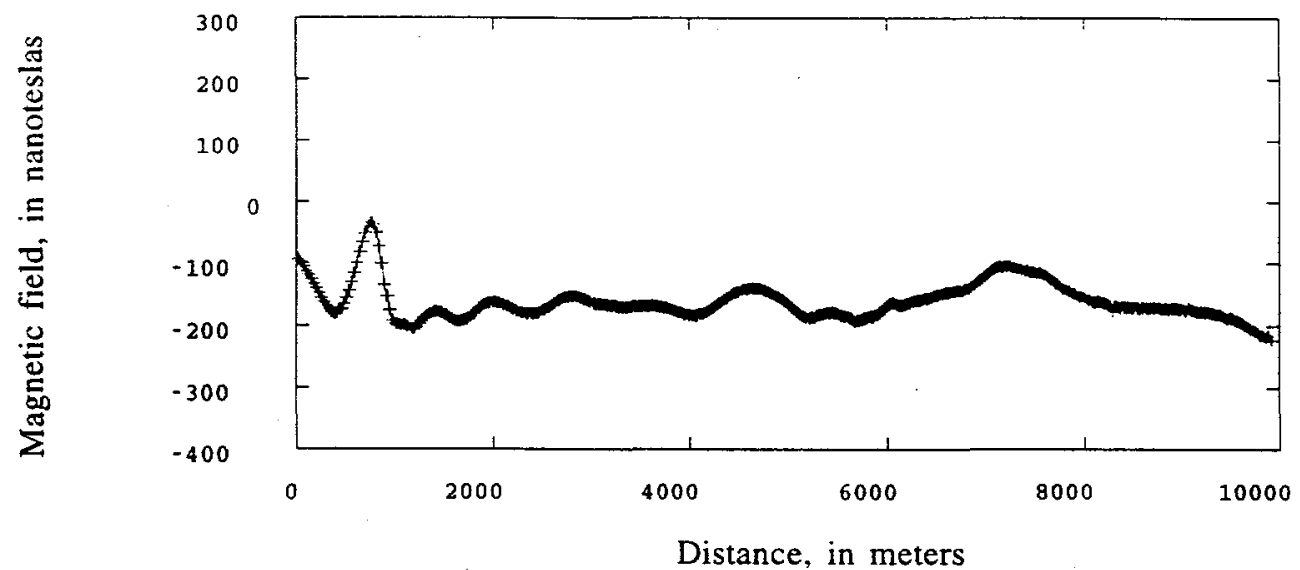

Figure 3-8. Aeromagnetic profile across Crater Flat and parts of Yucca Mountain, Nevada.

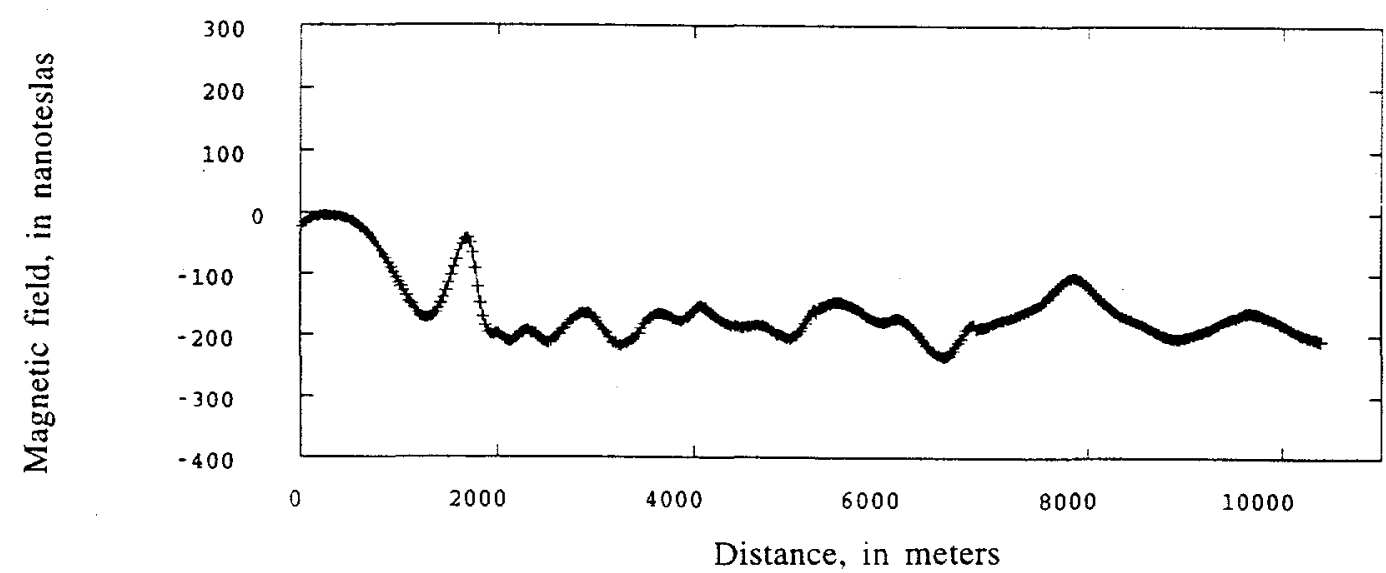

Figure 3-9. Aeromagnetic profile across Crater Flat and parts of Yucca Mountain, Nevada. 


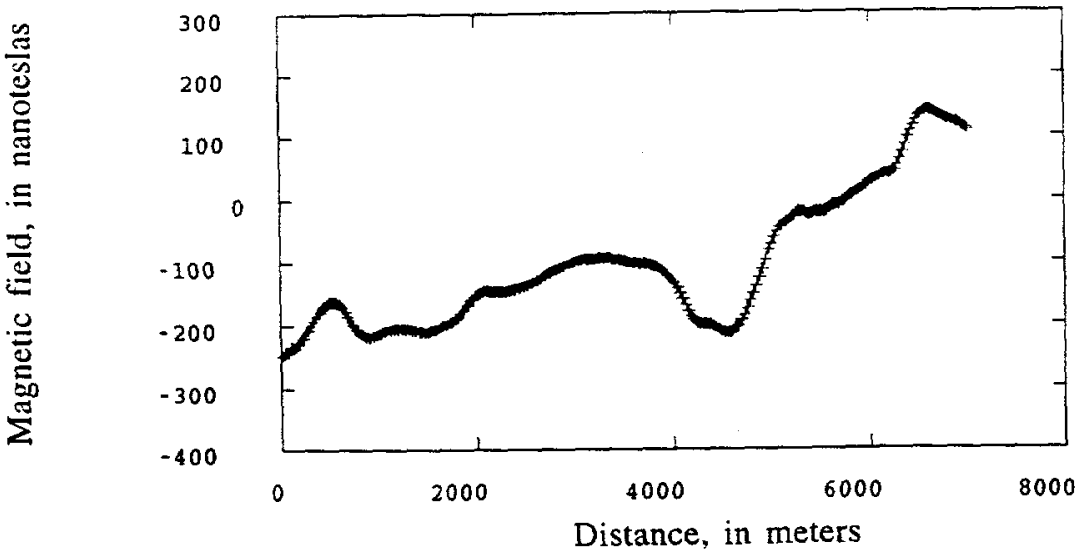

Figure 3-12. Aeromagnetic profile across Crater Flat and parts of Yucca Mountain, Nevada.

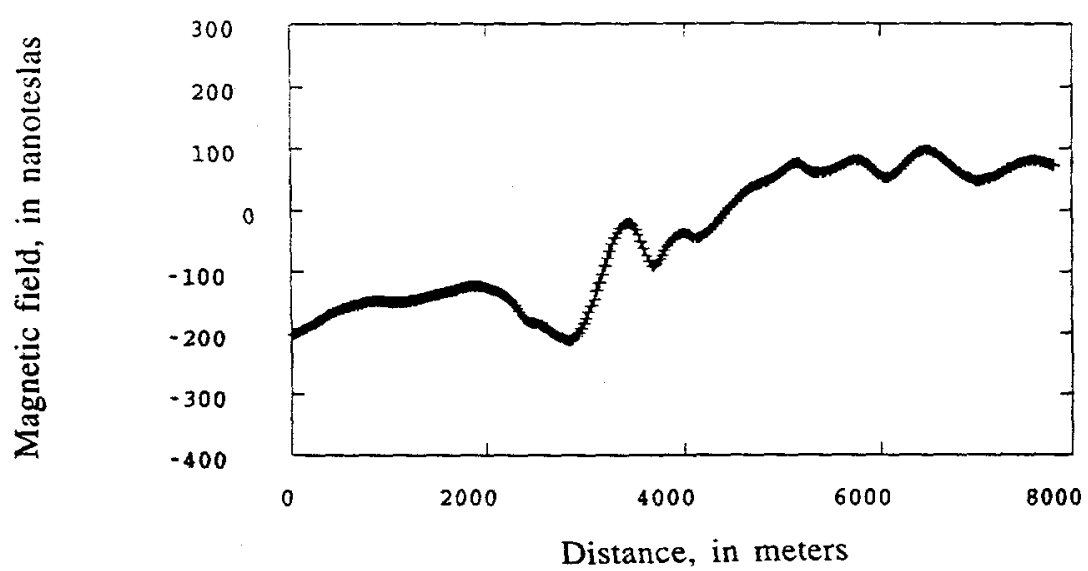

Figure 3-11. Aeromagnetic profile across Crater Flat and parts of Yucca Mountain, Nevada.

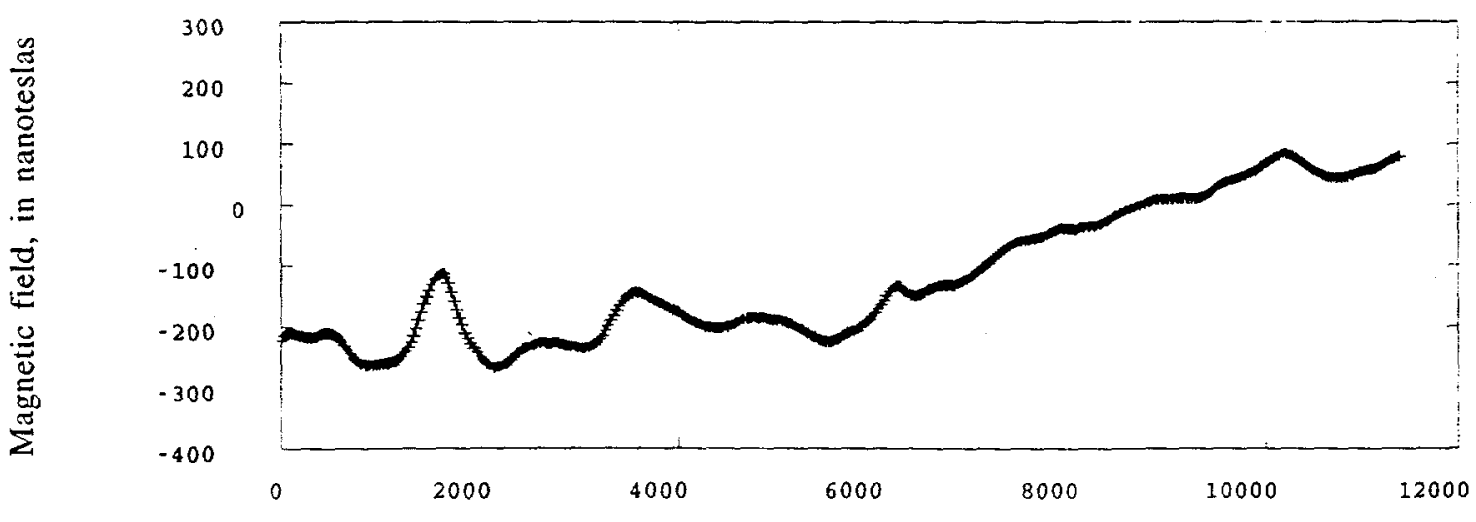

Distance, in meters

Figure 3-10. Aeromagnetic profile across Crater Flat and parts of Yucca Mountain, Nevada. 


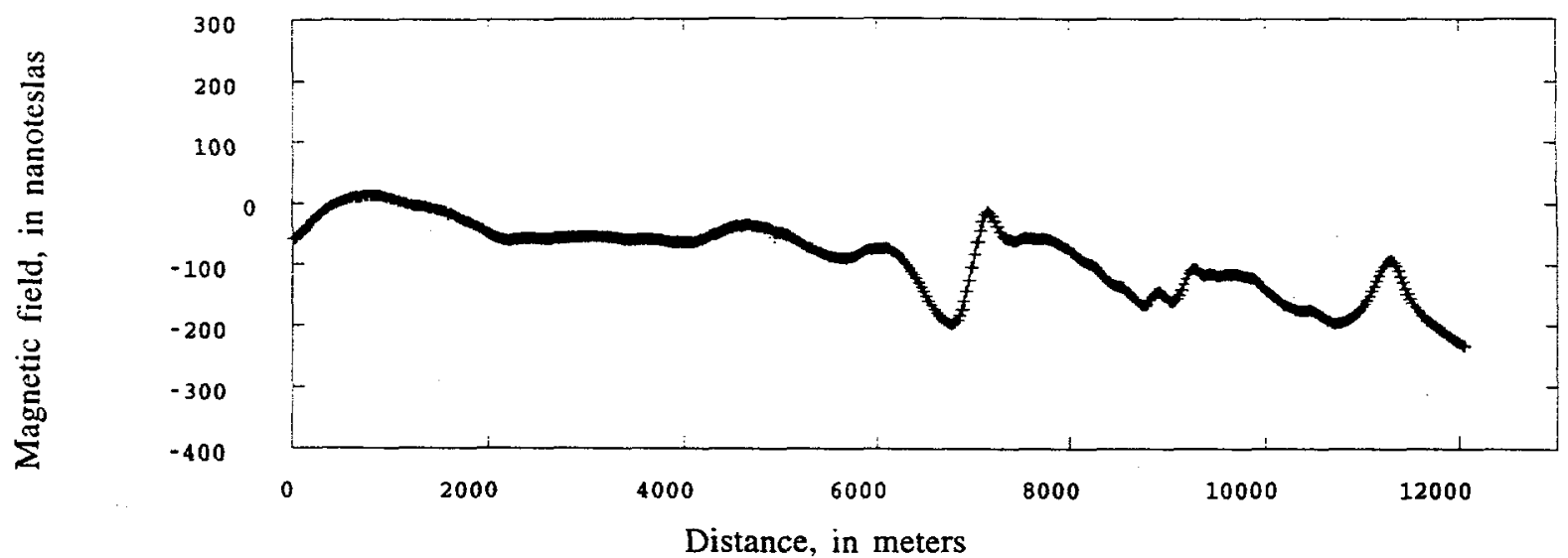

Figure 3-13. Aeromagnetic profile across Crater Flat and parts of Yucca Mountain, Nevada.

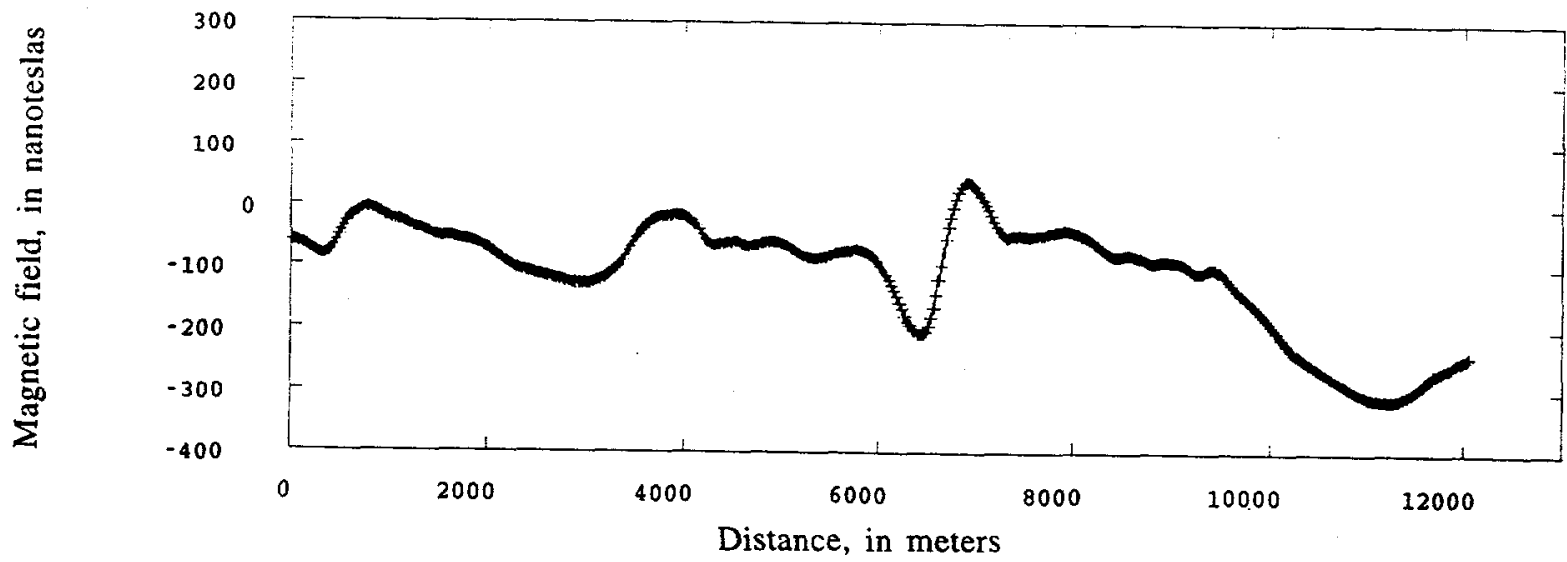

Figure 3-14. Aeromagnetic profile across Crater Flat and parts of Yucca Mountain, Nevada.

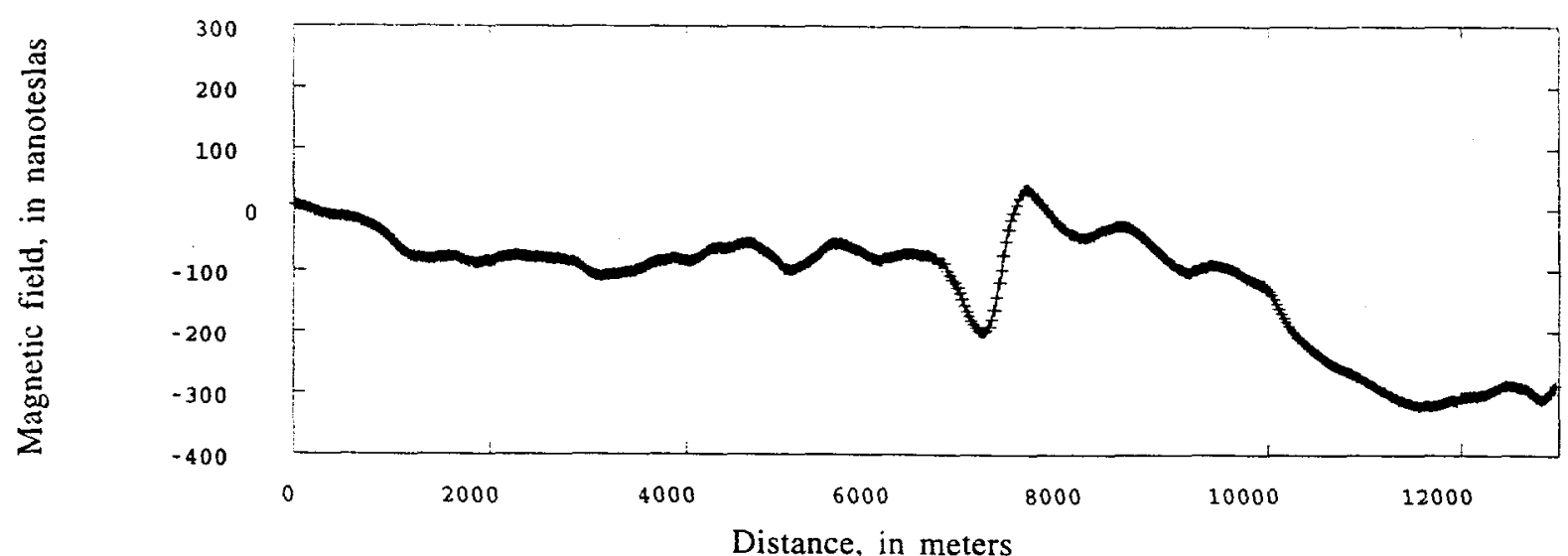

Figure 3-15. Aeromagnetic profile across Crater Flat and parts of Yucca Mountain, Nevada. 